instruments which Boyle used in his researches. There was another member of a noble family whom we are always glad to claim as a master among chemists: I mean Cavendish, who discovered the composition of water. He did much more than that, however, for he taught us that all experiments should be made with absolute accuracy as regards weight and measure. But what am I to say in answer to this toast? It is a large and important subject. I recollect it fifty years years ago. I am glad to say that not many of you have such an antique recollection of our science as that. The changes that have taken place in the science during that time have been vast indeed. Of course, our main object is to study chemical affinity, to understand the relations of the elements, and the families into which they group. One of the results of fifty years' advance in chemistry is that you have introduced a great deal of profligacy into the elements. When I was young we always taught that oxygen was the universal lover, and joined freely with almost every body, while nitrogen was a confirmed bachelor, and could only be put into union under great difficulty. But now, how completely this is all changed. Oxygen is now a respectable bigamist, while nitrogen, which acts so meekly in the atmosphere, when it gets out of it becomes a terrible polygamist, for it takes three and sometimes even five conjugates at a time, and produces bodies of a remarkable character. I have two friends, one of whom, Hofmann, is not here, but the other, Dr. Perkin, is, and they have done very much to corrupt the morality of the nitrogen of my youth. They have not only taught us what it can do in the way of conjugates, but have shown it to be a most fickle body, from whom you may take one conjugate and readily replace it by another, and thus produce most remarkable compounds. Sometimes they carried their efforts so far that nitrogen became apparently ashamed of itself, and blushed as rosanilin or became scarlet as magenta, and even, when moved by strong emotion, became purple as matuve. Occasionally chemists have tried to get nitrogen back to good habits, to be content with more simple conjugates, and be content with fewer elements in combination. But see how it revenges itself. Curtius and Radenhausen have lately described a most extraordinary compound-azoimide-in which three atoms of nitrogen unite with one atom of hydrogen. This was most unfair, for three atoms of nitrogen ought to have at least nine atoms of hydrogen. But they compelled it to do with one, and what is the consequence? They had to make it take the form of a liquid, and when in that condition it exploded with such violence as to break every glass vessel in the laboratory, and, I am sorry to say, injure one of the persons who tried to force it into this unnatural union. I have therefore some right to complain that the respectable nitrogen of my youth has become a most profligate element under your tuition. And what shall I say of carbon? How different was the carbon of 1841 from the carbon which we now know. At that time we knew, of course, that it was. combined in most organic bodies, and Liebig had determined the constitution of the bodies into which it entered, but then we did not require to puzzle ourselves with those fearful complications of diagrams and graphic methods by which we now represent the tenacity of carbon for various substances. These methods are very difficuit for the pupil to follow, and I am sure that if Cullen, who invented the system of chemical diagrams, could come to life again, and see the wonderful methods by which chemical combinations are now represented, he would ask to go back to his grave again and rest. Chemical substances now have such astounding properties. If there are two bodies which I thought I knew most thoroughly they are the quiet and respectable compounds called in my old professional days carbonic oxide and carbonic acid. But the respectable quiet carbonic oxide of I84I was shown the other day by Mond to run away with nickel in the state of a gas-a quiet stable element like nickel. And then when it was followed in hot pursuit, by raising the temperature a few degrees, it dropped the nickel like a hot potato. Well, I am speaking of the changes which strike a man looking backwards, and comparing the chemistry of his day with that of the present time. But though I have been chaffing in an after-dinner speech, do not think that I do not appreciate the vast progress that has been made in the discoveries relating to the valency of the elements. That has been the great distinguishing feature of modern chemistry. There is a great future before the chemistry of this country; and when the centenary of this Society takes place, the members will look back not without respect to the efforts we made in the first fifty years of the Society's existence. In conclusion, I must again thank Lord Salisbury for having honoured us on this occasion in the midst of his great and incessant duties, to show his appreciation of a science in which he has often laboured, and the value and importance of which he has recognized in the excellent speech before us.

\section{THE SCIENCE MUSEUM.}

THE question of the Science Museum which has been on the tapis for the last eighteen years, has moved -backwards-during the past week. The following question and answer will show how :--

"Sir Henry Roscoe asked the Chancellor of the Exchequer whether it was the case that an unknown donor had offered $£ 80,000$ to build an art gallery on a site at South Kensington, the erection of which would materially interfere with the purposes for which land was recently bought by Government for housing the science collections, and for the necessary erection of suitable chemical and physical laboratories in connection with the Royal School of Science; whether another site at South Kensington had been offered which would not interfere with the object for which Parliament granted the purchase-money for the land; and whether the Government would give an assurance that those objects would be maintained.

"The Chancellor of the Exchequer-It is true that a public-spirited gentleman has offered $£ 80,000$ to build an art gallery on a site at South Kensington; but with regard to the further points raised by the hon. member, I may say at once that the offer only affects about one-tenth of the land recently bought by Government, and the remainder would still be left available, if required, for science collections. No pledge was given that the whole of the land would be appropriated to science collections. On the contrary, the Treasury, in accepting the offer of the Commissioners of the $185 \mathrm{I}$ Exhibition, stated that the land was in excess of even future requirements of the science collections. It would be possible to make adequate provision for chemical and physical laboratories on the land between the Imperial Institute Road and the Technical Institute. This site adjoins the east galleries, and it is in these galleries, together with the west and southern galleries, and a proposed cross gallery joining the east and west galleries, that the science collections may ultimately be housed. The interests of the Royal School of Science, and of the science collections, are being carefully kept in view, and the hon. member will understand that the acceptance of this generous offer will enable us to provide adequate space for exhibition purposes more rapidly than would have been possible under the old scheme."

It thus appears that the ground which was bought to house collections illustrating science is to be used for some other purpose, since the present collections are to be permanently located in those galleries which, rightly or wrongly, are not considered by "the unknown donor" to be good enough for his pictures.

$$
\text { NO. I I I } 7 \text {, vOL. } 43]
$$


Further, since the new Art Gallery takes up nearly all the frontage of the Royal College of Science, the extension of that building, instead of being opposite, is to be built about 100 yards away on the opposite side of Exhibition Road, exactly over the projected railway. It is true the railway is postponed for this year, but that is no guarantee that it will not be proposed again.

Mr. Goschen appears to have given in to a caprice of an unknown donor without having any notion of the effect of his action. But if this be so, why does not Mr. Goschen abolish the Royal College of Science and the Science and Art Department altogether? This would be more statesmanlike than omitting to ask the opinions of people who are paid to advise on such matters. Can Mr. Goschen be of the same opinion as another great official who maintained that, even if it were conceded that there should be national collections of physical-science objects, as there are of pictures, books, beasts, birds, and the like, still little space would be required, "because there was no instrument a man of science used which could not be put into a hat"?

Certainly, if the absurd scheme sketched in $\mathrm{Mr}$. Goschen's answer is carried out, the intelligent foreigner will have a good time. He will have to determine whether English statesmanship has succeeded best in putting a physical laboratory over a railway which will prevent nine-tenths of the instruments being used, or in sandwiching a building devoted to art between the two halves of a science school.

\section{NOTES}

THE third session of the Australasian Association for the Advancement of Science was held in Christchurch, New Zealand, and began on January 15, 1891. Sir James Hector presided. The meeting was a successful one, the attendance being about 470 , and the number of papers read 74. Prof. Goodale, of Harvard University, represented the American Association, but no member of the British Association attended from England. A revised code of laws was adopted for confirmation at the next session. The evening lectures were: (I) "The Glaciers of the Tasman Valley," by G. E. Mannering; (2) "Oysters and Oyster-culture in Australasia," by W. Saville Kent ; and (3) "A Short History of Vocal Music," by G. F. Tendall. Ten Research Committees were appointed to report on different subjects to the next meeting, and a grant of $£ 25$ was made towards measuring the rate of motion of the New Zealand glaciers. As great inconvenience is often felt from the want of a special name for the sea between New Zealand and Australia, a recommendation was adopted that the Lords of the Admiralty be requested to name this sea the Tasman Sea. The Committee also recommended the appointment, by the British and American Associations, of a conjoint Committee to define the terms of general importance in biology; and that the Little Barrier Island north of New Zealand, and Resolution Island in Dusky Sound, be set apart as reserves, where the native fauna and flora of New Zealand may be preserved from destruction. The next session will be held at Hobart, Tasmania, with Sir Robert Hamilton, Governor of the Colony, as President.

The Vatican Observatory, which, according to a circular letter from Father Denza, the Director, "now revives under the protection of His Holiness the Pope Leo XIII.," is bestirring itself to come into closer communication with other scientific establishments, especially by way of the exchange of publications.

THE half-yearly general meeting of the Scottish Meteorological Society was held in Edinburgh yesterday. The Report from the Council of the Society was presented, and the following papers were read: on the winter of $1890-91$, by Dr. Buchan; silver thaw at the Ben Nevis Observatory, by R. C. Mossman.

$$
\text { xin rergive } 1,7
$$

THE Shaen Wing of Bedford College for Women, York Place, was opened by the Empress Frederick on Tuesday. On entering the College, the Empress was received by the visitor, Mr. N. Story Maskelyne, and the Chairman of Council, Dr. W. J. Russell. The ceremony took place in the large lectureroom, where there were present, among many others, Mrs. Shaen, Miss E. A. Shaen, Miss E. Shaen, Sir Henry Roscoe, Sir Lyon Playfair, General Donnelly, and Dr. Gladstone. Her Majesty having ascended the daïs, Mr. Maskelyne read an address, in the course of which he said :- "The literary and the art divisions of the College having been sufficiently provided with the necessary space and appointments, an addition to the buildings of the College for the teaching of science became imperative. This has been achieved, and laboratories for complete instruction in chemistry and the several branches of physics have been. built, and in part equipped. This addition has been called the Shaen wing, in order to connect permanently with the College the name of one who was always interested in its welfare, and who for 20 years had served on the Council, being elected Chairman of that body in 1880, an office which he held until his death. The sciences, with their vast influence on the one hand as intellectual triumphs, and on the other as mighty means for the material prosperity of the human race, are, and will be for ever, among the great monuments of the Victorian era. It is an encouragement for all interested in the higher training of women throughout the Empire and that of our kinsfolk in Germany to feel that the heart of the Royal race of England is with them in the effort to makethis higher training a heritage of our women as well as of our men." The Empress spent some time in the building after the ceremony was over, and expressed herself as greatly pleased with the College and the work it is doing.

LAST week, at the monthly general meeting of the Zoological Society, it was announced that in recognition of the effective protection accorded for sixty years to the Great Skua (Stercorarius: catarrhates) at two of its three British breeding stations-namely, in the island of Unst, by the late Dr. Laurence Edmondston, and other members of the same family, and in the island of Foula, by the late Dr. Scott, of Melby, and his son, Mr. Robert Scottthe silver medal of the Society had been awarded to Mrs. Edmondston, of Buness House, as representative of that family, and to Mr. Robert Scott, of Melby. The medals will be delivered to the medallists or their representatives after the close of the anniversary meeting on April 29 next.

THE following are the lecture arrangements at the Royal Institution after Easter:-Mr. J. Scott Keltie, three lectures on the geography of Africa, with special reference to the exploration, commercial development, and political partition of the continent; Dr. E. E. Klein, three lectures on Bacteria, their nature and functions (the Tyndall Lectures); Mr. William Archer, four lectures on four stages of stage history (the Betterton, the Cibber, the Garrick, and the Kemble periods); Prof. Dewar, six lectures on recent spectroscopic investigations; Dr. A. C. Mackenzie, four lectures on the orchestra considered in connection with the development of the overture; Prof. Silvanus P. Thompson, four lectures on the dynamo; Mr. H. Graham Harris, three lectures on the artificial production of cold ; Prof. A. H. Church, three lectures on the scientific study of decorative colour. The Friday evening meetings will be resumed on April Io, when a discourse will be given by Sir William Thomson, on electric and magnetic screening; succeeding discourses will probably be given by Prof. A. W. Rücker, the Rev. Canon Ainger, Mr. J. E. Harting, Prof. W. Ramsay, Prof. G. D. Liveing, Prof. J. A. Ewing, Dr. David Gill, Prof. Harold Dixon, and other gentlemen.

THE fourth annual exhibition of the Photographic Society of Philadelphia is to be opened on May 25. One of the three medals is to be for scientific or technical photography. 